\title{
Did the Bundesbank Target Monetary Expansion or Inflation? Evidence from Monetary Base Growth
}

\author{
Galina Boeva and Roland Vaubel ${ }^{\mathrm{b}}$
}

JEL-Classification: E52, E58, E42

Keywords: Deutsche Bundesbank, monetary policy, money supply targets, inflation targets

\section{Introduction}

In the last years prior to the introduction of the Euro, several empirical studies raised doubts whether the Bundesbank had been pursuing monetary targets. First, von HaGeN (1995) demonstrated that, in 1979-1993, the rate of monetary expansion had been uncorrelated with the announced target rate and that the deviations from target showed a significantly negative correlation with both the deviation of inflation from the underlying inflation objective and the rate of change of the real exchange rate. ${ }^{1}$ Second, Bernanke and Minov (1997) tested for Granger causality and found that the monthly variations of the German call rate were significantly affected by the expected inflation rate but not by the expected rate of monetary expansion (nor by the expected rate of change of industrial production and the nominal exchange rate). Moreover, the expected rate of inflation had a more significant effect on the Lombard rate than the expected rate of monetary expansion had. Third, Clarida and Gertler (1997) found that monthly variations in the German overnight rate among banks followed a Taylor rule, reacting significantly to the deviation of both (expected) inflation and industrial production from trend. Fourth, Clarida, Gali and Gertler (1998) added that this interest rate had also been significantly affected by the real exchange rate and the US federal funds rate but not by the deviation of monetary expansion from the preannounced target. Finally, SolveEn (1998) confirmed that

a Universität Mannheim, Abteilung Volkswirtschaftslehre.

b Professor, Lehrstuhl für Volkswirtschaftslehre, Politische Ökonomie, Universität Mannheim.

1 Neumann (1997) confirmed the second of these results. In his analysis, the deviation of monetary expansion from target also exhibited a significantly positive correlation with money demand shocks estimated as residuals from a velocity regression. By contrast, deviations of economic growth from potential did not have a significant effect. 
the short-term interest rate did not significantly respond to deviations of monetary expansion from target in a reaction function. ${ }^{2}$

At the time, the publication of these research results was of considerable political significance. Was the Bundesbank, one of the most successful inflation fighters of the world, not a monetary targeter after all? Did it pursue an inflation target instead? The issue is not whether the Bundesbank had an inflation objective. It had. It derived its monetary target from the inflation objective and assumptions about potential output growth and the velocity trend in a quantitytheoretic framework. The issue is whether it was committed to the announced money supply target or to the underlying inflation objective which it also published. Even though the money supply targets were derived from inflation objectives, they were considered superior to direct inflation targets because the money supply can be controlled much more closely than the inflation rate. Thus, the central bank's responsibility for missing the target is much clearer in the case of monetary targets. The incentive to pursue a money supply target is much stronger than the incentive to pursue an inflation target.

The above-mentioned econometric studies were bound to affect the monetary strategy of the future European Central Bank (ECB). The ECB did indeed adopt an inflation target band (from zero to two per cent) but announced a "reference rate" for monetary expansion (M3) as a concession to the monetarists. However, it did not take this indicator very seriously and in May 2003 delegated it to second rank. Some argue that it has been abandoned. None of the other participating central banks had been announcing money supply targets. They had been pegging to the deutschemark.

In the meantime, these studies have been criticized on several grounds. The first critic was Helmut Schlesinger, the former president of the Bundesbank. He emphasized that "money supply changes within the announced band, especially within the first months of the year, did not require any reaction but merely attention. Most of the econometricians ignore this and treat the mid-point of the band as the target" (SCHLESINGER, 2002: 147, our translation). We shall remedy this defect in the analysis of this paper.

Second, Gerberding, Worms and Seitz (2004) have criticized that these studies ignore the lag in the availability of data. Using real-time data, they find that the short-term interest rate reacted significantly to (i) the deviation of the

2 Subsequently, Kamps and Pierdzioch (2003) came to the same conclusion. For other recent estimates of Bundesbank reaction functions see Faust et al. (2001), HeInEmann and HüFner (2004), Clausen and Hayo (2005), Hayo and Hofmann (2006) and Hayo (2007). 
inflation rate from the underlying objective, (ii) expected output growth, (iii) the interest rate in the previous quarter and (iv) the deviation of monetary expansion from target. Clausen and Meier (2005), who also use real-time data, confirm this result in an error-correction model.

The third criticism which has been levelled against all these studies (except vON HAGEN, 1995) is that central bank policy is measured by some short-term interest rate. As Schlesinger (2002) has also stressed, a short-term interest rate, even if it is the central bank's main lending rate, fails to capture all its monetary policy actions. For example, changes in reserve requirements, changes in discount or Lombard credit lines and foreign exchange interventions are entirely ignored. The comprehensive measure of the central bank's policy actions is the monetary base adjusted for changes in reserve requirements. This aggregate is also likely to bear a closer relation to the money supply, the target variable, through the money multiplier ${ }^{3}$ than a short term interest is likely to do. For these reasons, the following analysis uses the adjusted monetary base.

\section{Hypotheses}

The main hypothesis to be tested in this paper is that changes in the Bundesbank's adjusted monetary base growth $(d b)$ reacted negatively to deviations of the money supply from its target. ${ }^{4}$ Thus, we hypothesize that adjusted monetary base growth $(b)$ is ceteris paribus constant (the change is zero) if the deviation of the money supply $(M)$ from target $\left(M^{*}\right)$ is zero. ${ }^{5}$ Since 1979, the first year of our time series, the targets have usually been defined as bands of two or three per cent. Thus, as has been explained, the deviations from target will be measured, first of all, as the deviations from the nearest margin of the target band $\left(M-M_{\text {mar }}^{*}\right)$. However, we shall also compare this with an estimate using the deviation from the midpoint of the band $\left(M-M_{\text {mid }}^{*}\right)$.

3 SCheIDe (1993) has shown that the DM multiplier has been highly predictable - even after monetary unification.

4 Until 1987, the target variable was "central bank money", thereafter the money supply M3. Central bank money in the definition of the Bundesbank was not the same as the monetary base but comprised the components of M3 weighted by constant values of their minimum reserve ratios.

5 Note that Clarida et al. (1998) regress the level rather than the change of their policy instrument, the short-term interest rate, on the deviation from monetary target. Thus, they test the hypothesis that the interest rate is ceteris paribus zero if the deviation from target is zero. 
We include three control variables which are commonly used in the literature:

- the change in the growth of production,

- the change in the rate of unemployment,

- the change in the DM / \$ exchange rate growth.

All explanatory variables are lagged.

Finally, we compare these two estimates of monetary targeting with two estimates of inflation targeting: (i) the lagged deviation of the inflation rate from the Bundesbank's inflation objective $\left(p_{t-1}-p_{t-1}^{*}\right)$ and (ii) the currently expected deviation $\left(E_{t}\left(p_{t}\right)-p_{t}^{*}\right)$ estimated from an ARMA $(2,2)$ process.

\section{Data}

The time series of our dependent variable starts in the third quarter of 1979 and ends in the last quarter of 1998 so that we have 78 observations. We do not include the period from 1975 to 1978 because our adjusted monetary base series contains a statistical break in June 1978 and because 1979 is generally considered the beginning of resolute monetary targeting by the Bundesbank. Our data are quarterly. The monetary base data have been seasonally adjusted using the additive Census-X12-ARIMA procedure.

The mid-points of the Bundesbank's money supply targets have been computed for each quarter by applying the target growth rate, announced in the fourth quarter of the preceding year, to the average money stock prevailing in the quarter in which the announcement was made. Then the limits of the target bands were calculated by applying the announced percentage margins to the target midpoints.

The inflation rate is measured by the Consumer Price Index and output by Gross Domestic Product. The data sources are listed in Appendix 1. 


\section{Estimates}

As all time series are stationary, we use ordinary least squares. ${ }^{6}$ As for the lags, all conventional information criteria (AIC, HQIC and SBIC) indicate a maximum lag of one quarter for all control variables. To deal with any remaining autocorrelation and heteroskedasticity we use the Newey-West variance estimator allowing for possible autocorrelation up to four quarters.

Table 1 contains our results. Columns 1 to 4 include only the hypothesized target variables, one by one, plus two dummies for the statistical break at the time of German re-unification (1990Q3 and 1990Q4) which are highly significant and contribute considerably to the explanatory power of the regression. As can be seen the deviation of money supply from its nearest target margin reduces the change of adjusted monetary base growth. The effect is significant at the 5 per cent level but not very large. If the deviation of money supply from the midpoint of the band is used instead, the coefficient decreases in absolute terms and is significant only at the 10 per cent level. By contrast, the inflation deviations as alternative potential target variables (columns 3 and 4) do not have a significant effect.

In columns 5 to 8 we add the change of real GDP growth, the change of the unemployment rate and the change of the DM/dollar exchange rate growth to each of the regressions 1 to 4 . The coefficient of the deviation of money supply from the nearest target margin decreases and its significance drops to the 10 per cent level (column 5); the coefficient of the deviation from the midpoint of the band now loses its significance completely (column 6). The coefficients of the control variables are also insignificant at conventional levels - but only marginally for the change in the unemployment rate. The inflation target variables remain completely insignificant (columns 7-8).

To analyze the statistical break further, we split the time series in 1990. The number of observations drops to 44 in the first subperiod (1979Q3 to 1990Q2) and 32 in the second (1991Q1 to 1998Q4). The Chow test shows that there is no significant structural break in regressions 1 and 2 .

6 We use the Augmented Dickey-Fuller test and the Phillips-Perron test. All time series are stationary according to both tests except for the expected deviation of inflation from target. However, this variable turns out to be stationary when using the modified Dickey-Fuller test proposed by Elliott, Rothenberg, and Stock (1996). 
Table 1: Changes of Adjusted Monetary Base Growth, 1979Q3-1998Q4

\begin{tabular}{|c|c|c|c|c|c|c|c|c|}
\hline & (1) & (2) & (3) & (4) & (5) & (6) & (7) & (8) \\
\hline intercept & $\begin{array}{l}.01 \\
(.15)\end{array}$ & $\begin{array}{l}.02 \\
(.21)\end{array}$ & $\begin{array}{l}-.04 \\
(.55)\end{array}$ & $\begin{array}{c}-.04 \\
(.53)\end{array}$ & $\begin{array}{l}-.06 \\
(.61)\end{array}$ & $\begin{array}{l}-.05 \\
(.55)\end{array}$ & $\begin{array}{l}-.09 \\
(1.11)\end{array}$ & $\begin{array}{l}-.09 \\
(1.10)\end{array}$ \\
\hline $\begin{array}{l}\text { deviation of money supply } \\
\text { from nearest target margin } \\
\text { in percent }(t-1)\end{array}$ & $\begin{array}{l}-.17^{* *} \\
(2.04)\end{array}$ & & & & $\begin{array}{l}-.15^{*} \\
(1.74)\end{array}$ & & & \\
\hline $\begin{array}{l}\text { deviation of money supply } \\
\text { from target midpoint } \\
\text { in percent }(t-1)\end{array}$ & & $\begin{array}{l}-.10^{*} \\
(1.85)\end{array}$ & & & & $\begin{array}{l}-.08 \\
(1.42)\end{array}$ & & \\
\hline $\begin{array}{l}\text { deviation of inflation } \\
\text { from objective }(t-1)\end{array}$ & & & $\begin{array}{l}-.00 \\
(.01)\end{array}$ & & & & $\begin{array}{l}-.08 \\
(1.12)\end{array}$ & \\
\hline $\begin{array}{l}\text { expected deviation of } \\
\text { inflation from objective }(t)\end{array}$ & & & & $\begin{array}{l}-.02 \\
(.23)\end{array}$ & & & & $\begin{array}{l}-.08 \\
(.98)\end{array}$ \\
\hline $\begin{array}{l}\text { change of real GDP growth } \\
(t-1)\end{array}$ & & & & & $\begin{array}{l}-.05 \\
(.82)\end{array}$ & $\begin{array}{l}-.05 \\
(.82)\end{array}$ & $\begin{array}{l}-.07 \\
(1.16)\end{array}$ & $\begin{array}{l}-.06 \\
(.95)\end{array}$ \\
\hline $\begin{array}{l}\text { change of unemployment } \\
\text { rate }(t-1)\end{array}$ & & & & & $\begin{array}{r}.82^{*} \\
(1.95)\end{array}$ & $\begin{array}{r}.80^{*} \\
(1.91)\end{array}$ & $\begin{array}{l}.97^{* *} \\
(2.42)\end{array}$ & $\begin{array}{l}.92^{* *} \\
(2.32)\end{array}$ \\
\hline $\begin{array}{l}\text { change of DM/dollar } \\
\text { exchange rate growth }(t-1)\end{array}$ & & & & & $\begin{array}{c}-.04 \\
(1.13)\end{array}$ & $\begin{array}{c}-.04 \\
(1.15)\end{array}$ & $\begin{array}{l}-.04 \\
(1.18)\end{array}$ & $\begin{array}{l}-.04 \\
(1.13)\end{array}$ \\
\hline $\begin{array}{l}\text { dummies for 1990Q3 } \\
\text { and Q4 }\end{array}$ & yes & yes & yes & yes & yes & yes & yes & yes \\
\hline $\operatorname{adj} . R^{2}$ & .60 & .60 & .59 & .59 & .61 & .62 & .61 & .61 \\
\hline
\end{tabular}

***/**/*: significant at $1 / 5 / 10$ percent level;

$t$-statistics in parentheses (computed from Newey-West standard errors).

\section{Conclusion}

Our analysis demonstrates that the changes of monetary base growth adjusted for changes in minimum reserve requirements, the summary measure of the Bundesbank's policy actions, responded negatively and significantly to deviations of money supply growth from the announced target if the deviation is correctly measured, namely, from the nearest margin of the announced target band. By contrast, if the deviation is measured from the mid-point of the target band, the coefficient decreases and its significance drops to the 10 per cent level. Deviations of current or expected inflation from the underlying inflation objective do 
not have a significant effect, regardless of whether control variables are added. The hypothesis that the Bundesbank has been an inflation targeter has to be rejected. Our results favor the hypothesis that the Bundesbank has targeted the money supply even though its effect on monetary base growth is fairly small and not robust to the addition of standard control variables.

\section{Appendix}

\section{Data: Definitions and Sources}

\begin{tabular}{|c|c|}
\hline Series & Definition and source \\
\hline Adjusted monetary base & $\begin{array}{l}\text { end of month; until 1990:6 West Germany; source: } \\
\text { Sachverständigenrat zur Begutachtung der gesamt- } \\
\text { wirtschaftlichen Lage (upon request) }\end{array}$ \\
\hline Consumer price index & $\begin{array}{l}\text { seasonally adjusted; source: Deutsche Bundesbank, } \\
\text { Saisonbereinigte Wirtschaftszahlen, Table III. } 23 \text { (new } \\
\text { classification) }\end{array}$ \\
\hline $\mathrm{DM} / \$$ exchange rate & $\begin{array}{l}\text { monthly or quarterly averages; source: Deutsche Bundesbank, } \\
\text { Monatsberichte, Table X.10 }\end{array}$ \\
\hline Gross domestic product (real) & $\begin{array}{l}\text { seasonally adjusted; source: Deutsche Bundesbank, } \\
\text { Saisonbereinigte Wirtschaftszahlen, Table II.1 (new } \\
\text { classification) }\end{array}$ \\
\hline M3 & $\begin{array}{l}\text { end of month data until 1989, monthly averages since 1990; } \\
\text { until 1990:12 West Germany; seasonally adjusted; source: } \\
\text { Deutsche Bundesbank, Saisonbereinigte Wirtschaftszahlen, } \\
\text { Table I.1 (new classification) }\end{array}$ \\
\hline Central bank money & $\begin{array}{l}\text { monthly averages, seasonally adjusted; source: Deutsche } \\
\text { Bundesbank, Monatsberichte, Table } 1.3\end{array}$ \\
\hline Unemployment rate & $\begin{array}{l}\text { as a per cent of employable persons in the non-military } \\
\text { sector; seasonally adjusted; source: Deutsche Bundesbank, } \\
\text { Saisonbereinigte Wirtschaftszahlen, Table II.8 (new } \\
\text { classification) }\end{array}$ \\
\hline
\end{tabular}




\section{References}

Bernanke, Ben S., and Ilian Mihov (1997), "What Does the Bundesbank Target?”, European Economic Review 41: pp. 1025-1053.

Clarida, Richard, and Mark Gertler (1997), "How the Bundesbank Conducts Monetary Policy", in Reducing Inflation: Motivation and Strategy, Christina D. and David H. Romer, eds., pp.363-412, Chicago: The Chicago University Press.

Clarida, Richard, Jordi Gali, and Mark Gertler (1998), "Monetary Policy Rules in Practice: Some International Evidence", European Economic Review 42: pp. 1033-1067.

Clausen, Volker, and Bernd Hayo (2005), "Monetary Policy in the Euroarea: Lessons from the First Years", International Economics and Economic Policy 1: pp. 349-364.

Clausen, Jens Richard, and Carsten-Patrick Meier (2005), "Did the Bundesbank Follow a Taylor rule? An Analysis Based on Real Time Data", Schweizerische Zeitschrift für Volkswirtschaft und Statistik 14: pp. 213-246.

Elliott, Graham, Thomas J. Rothenberg, and James H. Stock (1996), "Efficient Tests for an Autoregressive Unit Root", Econometrica 64: pp. 813-836.

Faust, Jon, John H. Rogers, and Jonathan H. Wright (2001), An Empirical Comparison of Bundesbank and ECB Monetary Policy Rules, International Finance Discussion Papers No.705, Federal Reserve Board, Washington, D.C.

Gerberding, Christina, Andreas Worms, and Franz Seitz (2004), How the Bundesbank Really Conducted Monetary Policy: An Analysis Based on Real-Time Data, Deutsche Bundesbank Discussion Paper Series No. 25/2004.

Hayo, Bernd, and Boris Hofmann (2006), "Comparing Monetary Policy Reaction Functions: ECB versus Bundesbank”, Empirical Economics 31: pp. 645-662.

Hayo, Bernd (2007), „Die Rolle der Geldmenge in der Geldpolitik und in der geldpolitischen Strategie“, Wirtschaftsdienst 87: pp. 10-14.

Heinemann, Friedrich, and Felix Hüfner (2004), "Is the View from the Eurotower Purely European?”, Scottish Journal of Political Economy 51: pp. 544-558.

Kamps, Christoph, and Christian Pierdzioch (2003), „Geldpolitik und vorausschauende Taylor-Regeln: Theorie und Empirie am Beispiel der Deutschen Bundesbank", WiSt 32: pp. 15-19.

Neumann, Manfred J.M. (1997), „Monetary Targeting in Germany“, in Towards More Effective Monetary Policy, Iwao Kuroda, ed., pp. 176-198, London: Macmillan. 
Schächter, Andrea (1999), Die geldpolitische Konzeption und das Steuerungsverfahren der Deutschen Bundesbank: Implikationen für die Europäische Zentralbank, Tübingen: Mohr Siebeck.

Scheide, Joachim (1993), „Deutsche Geldpolitik ohne Orientierung“, Konjunkturpolitik 39: pp. 100-120.

Schlesinger, Helmut (2002), „Die Bundesbank und die Geldmengenpolitik“, in Exogenität und Endogenität: Die Geldmenge in der Geschichte des ökonomischen Denkens und in der modernen Politik, Bertram Schefold, ed., pp. 137153, Marburg: Metropolis-Verlag.

Solveen, Ralph (1998), Der Einfluss der Unabhängigkeit auf die Politik der Zentralbanken, Tübingen: Mohr Siebeck.

von HaGen, Jürgen (1995), "Inflation und Monetary Targeting in Germany", in Inflation Targets, Leonardo Leiderman, Lars E. O. Svensson, eds., pp. 107121, London: Centre for Economic Policy Research.

\section{SUMMARY}

Several empirical studies have suggested that the Bundesbank has pursued inflation targets rather than monetary targets. These studies have been criticized because they do not adequately measure the deviation from target and because they use some short term interest rate as a measure of the Bundesbank's policy actions instead of the comprehensive measure, the monetary base adjusted for changes in reserve requirements. We find that, in the period from 1979 III to $1998 \mathrm{IV}$, changes in adjusted monetary base growth reacted negatively and significantly to deviations from target monetary expansion as measured relative to the nearest margin of the target band if, and only if, no control variables are added. With our control variables, the significance of this coefficient drops to 10 per cent. By contrast, deviations of the inflation rate from the inflation objective used to derive the money supply target never has any significant effect on changes in adjusted monetary base growth. This result holds regardless of whether the lagged or the currently expected inflation rate is employed. The results are consistent with money supply targeting (if anything) but not with inflation targeting. 